\title{
A Study Revelation on Market and Value-Realization of Ecological Product to the Control of Rocky Desertification in South China Karst
}

\author{
Haiting Shen ${ }^{1}$, Ziqi Liu ${ }^{1}$, Kangning Xiong ${ }^{1, *}$ and Liang Li $^{1,2}$ \\ 1 School of Karst Science, Guizhou Normal University/State Engineering Technology Institute for Karst \\ Desertification Control, Guiyang 550001, China; huangjinli0320@163.com (H.S.); \\ 201511004@gznu.edu.cn (Z.L.); bsjy_11@126.com (L.L.) \\ 2 School of Management Science, Guizhou University of Finance and Economics, Guiyang 550025, China \\ * Correspondence: xiongkn@163.com
}

check for updates

Citation: Shen, H.; Liu, Z.; Xiong, K.; Li, L. A Study Revelation on Market and Value-Realization of Ecological Product to the Control of Rocky Desertification in South China Karst. Sustainability 2022, 14, 3060. https:// doi.org/10.3390/su14053060

Academic Editor: Antonio Boggia

Received: 3 November 2021

Accepted: 1 March 2022

Published: 5 March 2022

Publisher's Note: MDPI stays neutral with regard to jurisdictional claims in published maps and institutional affiliations.

Copyright: () 2022 by the authors. Licensee MDPI, Basel, Switzerland. This article is an open access article distributed under the terms and conditions of the Creative Commons Attribution (CC BY) license (https:// creativecommons.org/licenses/by/ $4.0 /)$.

\begin{abstract}
The restoration of the ecological environment in rocky desertification areas and economic development go hand in hand. With the support of the national policies from the "Ninth Five-Year Plan" to the "Thirteenth Five-Year Plan", the related ecological industries and products derived from the control of rocky desertification in karst areas continue to emerge. It not only restrains and repairs the development of rocky desertification but also produces a higher regional economic value than the replaced industry, which has practical significance for targeted poverty alleviation and rural revitalization in rocky desertification areas. The thesis classifies and summarizes the development status of ecological products from the perspectives of the basic theory of ecological products, industrial model construction, industrial demonstration, quality monitoring and evaluation, product sales space, product value realization and improvement research and proposes some scientific problems to be solved. The dual attributes of ecology and economy of ecological products are integrated, and a sustainable industrial model and industrial value-added enlightenment for consolidating the achievements of rocky desertification control is proposed.
\end{abstract}

Keywords: eco-products; sales spatial pattern; market value; karst rocky desertification control

\section{Introduction}

South China Karst is an area with the largest exposure area of the three karst concentration areas in the world. Its special natural environment leads to a fragile and sensitive ecosystem [1-3]. Coupled with the unreasonable social and economic activities of human beings, the contradiction between man and land is prominent, and different degrees of land degradation-e.g., rocky desertification-have appeared. The problem of rocky desertification is called "Ecological cancer", which causes the dual poverty of ecology and economy in the karst area, which is the key and most difficult point of ecological civilization construction and the main battlefield of National Poverty Alleviation [4,5].

The ecoindustrial governance model is a win-win model between rocky desertification control and regional economic development in karst areas. From the Ninth Five-Year plan to the 13th Five-Year Plan, the Chinese government has continuously provided policy support, technological innovation, and financial guarantee for karst areas. The report of the 18th CPC National Congress also clearly pointed out the need to vigorously promote the construction of ecological civilization, enhance the production capacity of ecological products and promote the comprehensive management of rocky desertification [6-8]. To seek the healthy development of ecology and economy in karst areas, many scientific researchers have explored ecological industries suitable for local rocky desertification control and economic development in combination with the fragile karst environment and local reality and formed an ecological industry technology and promotion model for comprehensive rocky 
desertification control. In the governance model, the ecological industry model considers socio-economic development and environmental restoration $[9,10]$. It is favored by farmers and scientific and technological personnel and is widely promoted, forming derivative ecological industries and products under the governance of karst rocky desertification. In this way, quantitative evaluation of the effect of rock desertification control, especially under the control of the industrial model, and the effect of new and old industries on farmers income have become important references and important paths for the evaluation of rock desertification control. It is also an important path to realize the value of ecological products. The most important way to commercialize the ecological products industry is to explore the market supply and demand of ecological products with the support of technology, improve the quality of ecological products, increase the added-value of products and further expand the sales market of ecological products. Therefore, research on the promotion of ecological products' sales spaces and market values is particularly important.

At present, the development of the ecological industry has covered the entire industrial chain from technology and production to sales. The ecological derivative industry of karst rocky desertification control has extended from basic theoretical research to model construction, industrial demonstration, monitoring and evaluation, sales space, value realization and so on. This paper summarizes the research on the ecological industry of karst rocky desertification control by scholars at home and abroad in the last 50 years, including the main achievements of this research on the scale, industrialization and commercialization of the ecological industry, and classifies and summarizes it according to the year, region, unit and content. On this basis, this paper puts forward the scientific problems to be solved and the enlightenment of rocky desertification control experience. It is expected that this review will provide a scientific basis for future rocky desertification control work, promote the smooth promotion of rocky desertification control projects and realize the unity of ecological and economic benefits of karst fragile ecological environment.

\section{Materials and Methods}

The literature search was carried out based on the China National Knowledge Infrastructure (CNKI) and the Web of Science (WOS) Core database. "Karst", "Rocky designation", "ecological industry", "eco products", "market", "spatial pattern" and "value enhancement" are the search terms in both Chinese and English. The retrieved Chinese and English literatures were manually screened, and the screening methods were as follows:

First, duplicate literatures were eliminated, leaving 308 articles; secondly, 65 articles were removed by manually filtering article titles and abstracts; finally, by reading the full text, only the relevant literatures such as ecological product industry model, market space and value enhancement are retained for final analysis.

To sum up, a total of 207 documents were obtained: 121 Chinese documents, including 86 periodical documents, 7 conference documents ( 5 domestic conferences and 2 international conferences), 17 Dissertations (6 masters and 11 doctors), 5 newspapers and 6 books. There are 76 foreign periodical literatures. It should be noted that the references listed at the end of this paper are all references cited in this research paper, and the rest are not listed.

Based on these results, we analyzed the literature using statistical analysis software. The literature statistics were conducted in Excel, the graphs were made using Origin software and the analysis performed in both allowed us to obtain the distribution of literature by year, content, region, unit and to identify different trends in literature growth.

\subsection{Annual Distribution of Literature}

The research on ecological industry and products began abroad in the 1970s, while China's research on it was a little later than that abroad, starting in the early 1980s. Through analysis, the research on ecological industries and products and their spatial pattern, value realization and promotion can be roughly divided into three stages from 1970 to 2021. In the first stage, before 1980, the total number of documents was no more than 10, and the number of documents per year was no more than 2 , which was in the embryonic stage; the 
second stage was from 1980 to 2003, showing an upward and downward trend and a period of slow growth, which is also the stage in which countries all over the world began to focus on the topic; in the third stage, from 2003 to 2021, sustainable development has become the trend of global development. The ecological industry is booming, and the number of related documents also shows a rapid growth trend. The average annual literature is more than 5 papers. The research content has gradually deepened from theoretical research to ecological industry model construction and ecological industry demonstration. Until the ecological products go to the market, the product market spatial distribution patterns and values are improved (Figure 1).

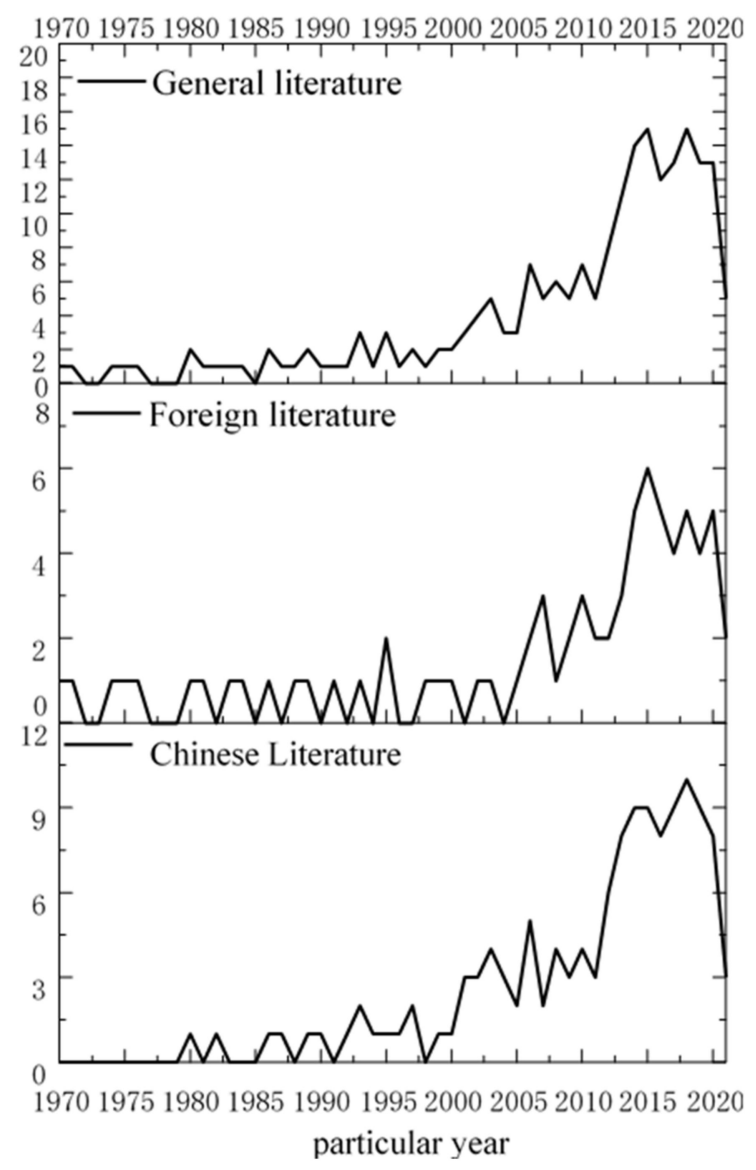

Figure 1. Distribution of domestic and foreign research literature from 1970 to 2021.

\subsection{Literature Type Classification}

According to the progressive principle of the comprehensive control of rocky desertification, the literature is divided into six aspects [11]. Among them, basic research literature accounts for $35.28 \%$, model construction literature accounts for $20.10 \%$, industrial demonstration literature accounts for $18.82 \%$, monitoring and evaluation literature accounts for $11.03 \%$, market space literature accounts for $5.25 \%$ and value realization and promotion literature accounts for $9.52 \%$. This shows that in the Ninth Five-Year Plan, theoretical basic research has always been the top priority of rocky desertification control, and rich research results have been accumulated with each stage of rocky desertification control. The research on the industrial demonstration, market space, value realization and promotion of ecological products is still in the stage of continuous exploration and development.

\subsection{Regional and National Distribution of Literature}

Among the 207 documents reviewed, foreign language documents are mainly concentrated in Europe, North America, Asia and Oceania (Figure 2). Before the 1970s, ecological industries first appeared in developed countries. The continuous acceleration of industrial- 
ization has brought about global ecological and environmental problems such as resource depletion, air pollution, water pollution, a sharp decline in forests, land desertification and environmental pollution, and the ecological industry has received high attention. In the 1970s, with the spillover of knowledge, Southeast Asia and East Asia began to study ecological agriculture. The Maya farm in the Philippines was used as a case. Agro-industrial co-production has been realized; that is, it can maintain high profits without purchasing raw materials, fuels or fertilizers from outside. In addition, there is no pollution from waste gas, wastewater and waste residue. As climate and environmental issues have been hotly discussed by Western countries and have become a global focus, the concept of ecological industry has always occupied the global voice. Therefore, the number of relevant documents is led by Western developed countries.

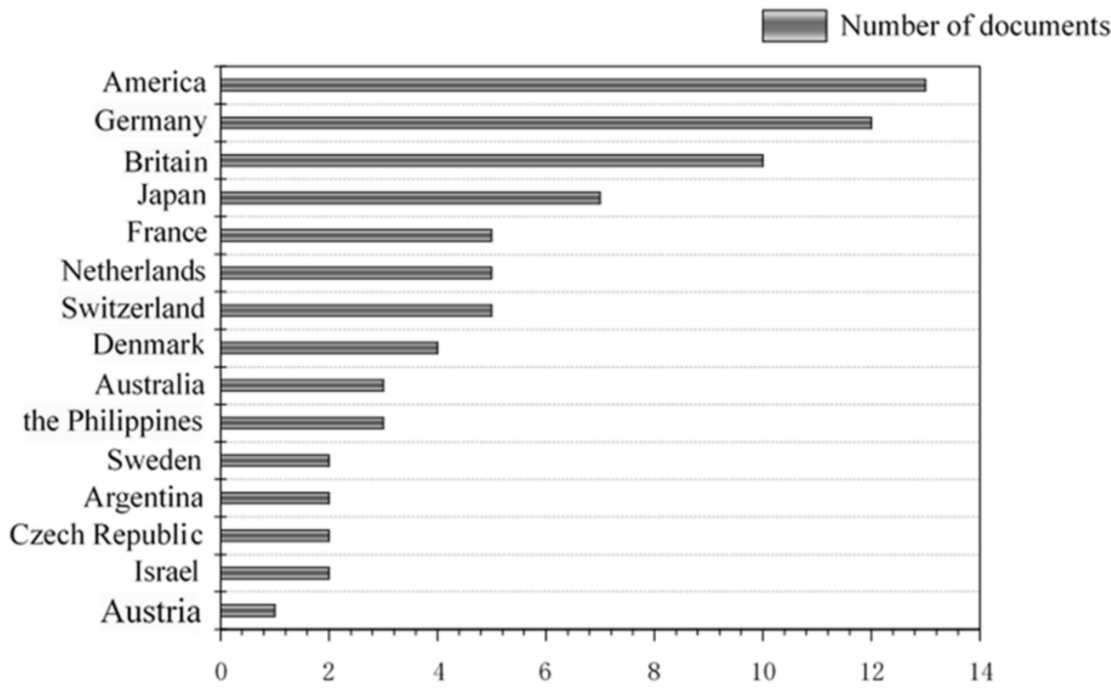

Figure 2. Regional and National distribution of literature from 1970 to 2021.

\subsection{Literature Unit Distribution}

Therefore, there are many research units in the literature. Due to the limitation of chart space, only 14 units with more than 3 published documents are counted. The top four are the Chinese Academy of Sciences (17), Northwest University of agriculture and forestry science and Technology (14), Beijing Forestry University (9), Nanjing Agricultural University (5) and Shandong Agricultural University (3), all of which are domestic universities. Among all research institutions, there are more domestic research institutions than foreign ones, and there are more universities and scientific research institutions than production units and companies. The reason for this may be the limited retrieval of foreign journals and language differences, which may lead to a certain deviation from the actual situation. Among all the top research institutions, they are almost all agricultural, economic, ecological and environmental protection colleges or institutions, and they are all in areas where agriculture and economy are more developed (Figure 3).

\subsection{Division of Research Stages}

According to the review of research literature, the research on the sales space of ecological products and the realization and promotion of market value sprouted and developed in the 1970s and has a history of nearly 50 years. Combined with the research background on the development of basic theory of ecological industrial products, the emergence of value realization and promotion technology, the distribution of market sales' space pattern and other stage changes during this period. The research on the market sales space, value realization and promotion of ecoindustrial products is divided into three stages, namely, the initial stage, the slow development stage and the high-speed growth stage (Table 1 ). 


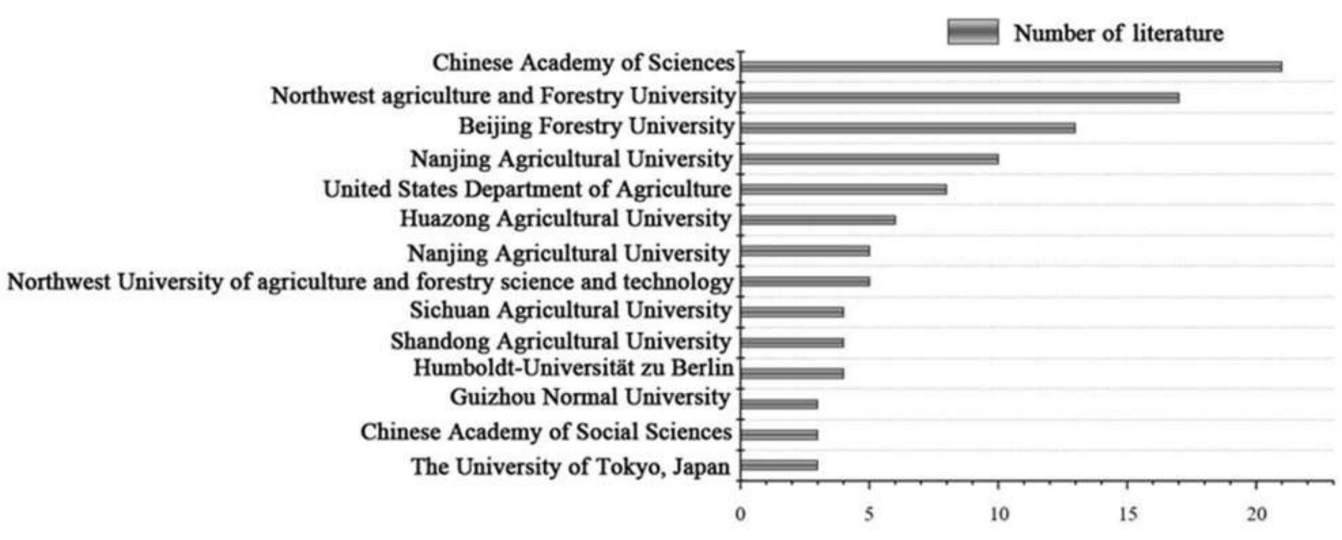

Figure 3. Literature unit distribution from 1970 to 2021.

Table 1. Research phase division of supply and demand space and value enhancement of ecological derivatives of rocky desertification control from 1970 to 2021.

\begin{tabular}{|c|c|c|c|}
\hline Research Stage & Development Background & Main Features & Most Cited Articles \\
\hline $\begin{array}{c}\text { Embryonic stage } \\
\text { (Before 1980) }\end{array}$ & $\begin{array}{l}\text { The research is based on the } \\
\text { concept and scope of the ecological } \\
\text { industry, and the ecological } \\
\text { industry is in the embryonic stage. }\end{array}$ & $\begin{array}{l}\text { In 1972, human beings first proposed to } \\
\text { protect the ecological environment, and } \\
\text { Western countries began to study } \\
\text { environmental protection. There are few } \\
\text { related documents that have been } \\
\text { consulted, and some of them have been } \\
\text { blank for a few years, and qualitative } \\
\text { introductions are most common. }\end{array}$ & $\begin{array}{l}\text { Engineering for } \\
\text { Ecological, } \\
\text { Sociological, and } \\
\text { Economic } \\
\text { Compatibility [12] }\end{array}$ \\
\hline $\begin{array}{l}\text { Slow growth stage } \\
\quad(1981-2002)\end{array}$ & $\begin{array}{l}\text { With the advancement of social } \\
\text { science and technology, the } \\
\text { ecological industry has gradually } \\
\text { been recognized by the world. It } \\
\text { has highlighted its advantages in } \\
\text { the international market, and the } \\
\text { ecological industry model has }\end{array}$ & $\begin{array}{l}\text { Relevant journal articles are published } \\
\text { every year, and the research content } \\
\text { initially involves the construction of } \\
\text { ecological industry model, technology } \\
\text { research and development, monitoring and } \\
\text { evaluation. Quantitative research has } \\
\text { begun to increase, and research methods }\end{array}$ & $\begin{array}{l}\text { The Refinement of } \\
\text { Production. Ecological } \\
\text { Modernization Theory } \\
\text { and The Chemical } \\
\text { Industry [13] }\end{array}$ \\
\hline $\begin{array}{l}\text { development stage } \\
\text { (2003 present) }\end{array}$ & $\begin{array}{l}\text { People's demand for ecological } \\
\text { products is increasing day by day. } \\
\text { The contradiction between human } \\
\text { development and the natural } \\
\text { environment is becoming more and } \\
\text { more acute. The ecological and } \\
\text { social and economic benefits of } \\
\text { ecological products are getting } \\
\text { more and more attention. }\end{array}$ & $\begin{array}{l}\text { Since 2003, the average number of } \\
\text { published documents on ecological } \\
\text { products has been around } 10 \text { per year. } \\
\text { Various government support policies have } \\
\text { been promulgated one after another, } \\
\text { technology R\&D is more standardized and } \\
\text { specific, applied literature is dominant and } \\
\text { research methods are becoming more and } \\
\text { more scientific. }\end{array}$ & $\begin{array}{c}\text { Concept, Classification } \\
\text { and Market Supply } \\
\text { Mechanism of } \\
\text { Ecological Products } \\
{[14]}\end{array}$ \\
\hline
\end{tabular}

\section{Main Developments and Landmark Achievements}

\subsection{Basic Theory}

\subsubsection{Low Added Value of Ecological Products}

"Ecological products" is a unique Chinese concept, which is similar in nature to the ecosystem services that developed countries are concerned about $[15,16]$. Western developed industrialized countries faced ecological environment problems earlier than us and realized the importance of natural systems to provide comprehensive services. In 2010, China put forward the concept of ecological products for the first time in the "National Main Function Area Planning (Guo Fa [2010] No. 46)", which is a core concept of ecological civilization construction. The general development process of ecological product value realization from concept to practice is shown in Table 2. Therefore, this paper classifies the development of ecological products, including the integration of production 
and sales of ecological products from production to market. Ecological products can come from original ecosystems or from ecosystems that have restored their service functions after inputting human labor and corresponding social material resources [14]. Therefore, ecological derivatives appearing after karst rocky desertification control are also ecological products. The fragile karst environment has high requirements for human activities [17], and developing ecological industries is the only way to consolidate the achievements of rocky desertification control. In the early stage of ecological industry development, agricultural development is the focus, so there are more primary ecological products, the added value of products is low and the economic benefits brought by products are also low. Reasonably expanding the supply capacity of ecological products and improving the ecological industrial structure in the karst area are the top priorities for obtaining higher economic benefits.

Table 2. Development of Eco-Product Concepts in Chinese Policy Papers from 2010-2021. Data Sources: http:/ / www.gov.cn (accessed on 8 February 2022).

\begin{tabular}{|c|c|c|}
\hline Years & Literature & Main Content \\
\hline 2010 & National main functional area planning & $\begin{array}{l}\text { The concept of ecological products was proposed for } \\
\text { the first time, emphasizing that ecological products are } \\
\text { the function of ecosystems to provide ecological } \\
\text { regulation }\end{array}$ \\
\hline 2012 & $\begin{array}{l}\text { Report of the 18th National Congress of the } \\
\text { Communist Party of China }\end{array}$ & $\begin{array}{c}\text { Emphasis on enhancing productivity of ecological } \\
\text { products }\end{array}$ \\
\hline 2015 & "Thirteenth Five-Year Plan" & $\begin{array}{c}\text { Emphasis on the provision of higher quality ecological } \\
\text { products }\end{array}$ \\
\hline 2016 & $\begin{array}{l}\text { National Ecological Protection "Thirteenth Five-Year } \\
\text { Plan" Outline }\end{array}$ & $\begin{array}{c}\text { Emphasis on expanding the supply of ecological } \\
\text { products and further clarifying the specific } \\
\text { connotation of ecological products }\end{array}$ \\
\hline 2016 & $\begin{array}{l}\text { Opinions on Improving the Ecological Protection } \\
\text { Compensation Mechanism }\end{array}$ & $\begin{array}{l}\text { Two main supply modes of ecological products are } \\
\text { clarified, namely, ecological compensation and market } \\
\text { transactions }\end{array}$ \\
\hline 2016 & $\begin{array}{c}\text { Implementation Plan of the National Ecological } \\
\text { Civilization Pilot Zone (Fujian) }\end{array}$ & $\begin{array}{l}\text { The practical exploration of ecological product value } \\
\text { realization will start in the main ecological civilization } \\
\text { pilot area }\end{array}$ \\
\hline 2017 & $\begin{array}{c}\text { Report of the 19th National Congress of the } \\
\text { Communist Party of China }\end{array}$ & $\begin{array}{l}\text { The national goal of supplying ecological products } \\
\text { was clarified }\end{array}$ \\
\hline 2018 & $\begin{array}{l}\text { Speech by General Secretary Xi Jinping at the } \\
\text { Symposium on Deepening the Development of the } \\
\text { Yangtze River Economic Belt }\end{array}$ & $\begin{array}{l}\text { Clarified the direction and specific requirements of the } \\
\text { path to realize the value of ecological products }\end{array}$ \\
\hline 2019 & $\begin{array}{l}\text { Opinions on supporting Zhejiang Lishui to carry out } \\
\text { the pilot project of ecological product value realization } \\
\text { mechanism }\end{array}$ & $\begin{array}{l}\text { Propose the concept of ecological product value } \\
\text { realization mechanism and start the special practice } \\
\text { exploration at the prefecture level }\end{array}$ \\
\hline 2021 & $\begin{array}{l}\text { Opinions on Establishing and Improving the Value } \\
\text { Realization Mechanism of Ecological Products }\end{array}$ & $\begin{array}{l}\text { Establish ecological product investigation and } \\
\text { monitoring mechanism, value evaluation mechanism, } \\
\text { management and development mechanism, protection } \\
\text { compensation mechanism, value realization guarantee } \\
\text { and promotion mechanism }\end{array}$ \\
\hline
\end{tabular}

\subsubsection{Ecological Products Have Dual Properties}

The production process of ecological products condenses general and undifferentiated human labor. It needs market exchange to realize its value. From the perspective of demand, high-quality ecological products are indispensable for the normal life of human beings, but most of the products have the characteristics of being regional, difficult to measure, partitioned and invisible, and it is impossible to buy and sell them in the market like general material commodities [18]. The relationship between ecological products and basic human values is a special one. Therefore, ecological products not only have their own ecological attributes but also unique economic and social attributes. The diversity of its inherent attributes determines that the research on ecological products should be diversified, and 
three-dimensional, and comprehensive research should be conducted from multiple angles and levels [19]. Ecological products improve the utilization rate of resources and labor productivity. Ecological products are designed and transformed according to the principle of "integration, coordination, recycling and regeneration", including the transformation of the energy structure, such as the development and utilization of solar energy, natural energy and bioenergy and the effective utilization of mineral energy [20]. The realization of ecological value, on the one hand, reflects the principle of high-quality production at a better price and, on the other hand, implements the economicalization of ecological benefits, thereby promoting the environmental protection of the enterprise from the social welfare type to the economic profit type, so it has invested more manpower. The market prices of materials and technology are slightly higher than that of general commodities. This may be at a disadvantage in the competition of similar general commodities. In this case, it is necessary to find more competitive ecological products.

\subsection{Pattern Construction}

\subsubsection{Various Modes of Ecological Governance of Karst Rocky Desertification}

The rocky desertification areas in Guizhou have prominent contradictions between people and land (mainly due to large population and large proportion of agricultural population). They are generally faced with three major problems: economic poverty (lack of food and money), poor living environment conditions (low vegetation coverage, difficulty in sourcing drinking water for people and livestock, frequent karst drought and flood disasters, etc.) and insufficient potential for regional sustainable development (single rural industrial structure, lack of alternative industries and new economic growth points) [21,22]. Therefore, the rocky desertification control model should be explored from the aspects of different karst landform types, different levels of rocky desertification, different rocky desertification types and different site conditions. Moreover, on the basis of following the principle of species adaptability, the principle of combining long- and short-term, the principle of hierarchy and sequence, the principle of ecological compensation and the principle of market orientation, the coordination and unity of ecological benefits, economic benefits and social benefits is sought after [23]. In recent years, various scientific research institutions and local forestry, agriculture, water conservancy, animal husbandry and other departments have made technological breakthroughs in the implementation of key national scientific and technological projects, namely, the Yangtze River improvement project and the Pearl River improvement project. In the field of the comprehensive control of rocky desertification, many models and application technology systems with practical application value have been proposed, which play an important guiding role in the comprehensive control of rocky desertification in Guizhou $[7,23]$. Based on the key problems of rocky desertification and the technical measures taken by the control model, the constructed rocky desertification control models include seven categories: a vegetation restoration model of forest and grass [9], a soil and water conservation model [10], a development model of herbivorous animal husbandry [11], an ecological agricultural model [21], a tourism mode of ecological reserves [24], a comprehensive governance model [25] and an ecological migration model [26]. Karst rocky desertification control has established different control models from different angles, but the landform and geology of karst areas are complex, and it is difficult is difficult to achieve the desired effect with a single model.

\subsubsection{Ecological Industry Models in Karst Areas Are Diverse}

Ecological industry is dominated by ecological theory, organically combining traditional agricultural experience and modern agricultural technology and planning, organizing and producing new models of modern agricultural development according to local conditions [14]. It is an organic system that includes the ecological environment and living conditions of industry, agriculture, residential areas and so on. Therefore, it spans the primary production sector, the secondary production sector and the service sector, including eco-industry, eco-agriculture and eco-service industries [27]. At present, the main and 
large-scale ecological industry models in the karst area are as follows: the company is the leading enterprise, the farmers are the industrial workers, the establishment of commodity production bases and the market-oriented comprehensive agricultural development and operation model [23]; an agricultural product base centered on "market + standard + technology + management + environmental protection + insurance + base + company + farmer + government key support", forming a highly intensive, high-quality, efficient and safe production model [28]; a three-dimensional agro-ecological model for planting vegetables, medicinal materials and other economic crops or breeding chickens and ducks in open space in forests; and fruit row spacing by using the temporal and spatial differences and complementary relationships between crops, forests and fruits during growth. Not only can these models improve the utilization rate of land and increase economic benefits, but they can also protect soil, reduce soil erosion and reduce pests and diseases [29] It is a comprehensive utilization model of waste resources based on the development of cow dung, pig dung, chicken dung and other wastes in the breeding industry or the use of biological and microbial process measures [30]; the forest belt model around the city is mainly formed by returning farmland to forests, closing mountains for afforestation and maintaining natural forests [31]. The construction of these poverty alleviation models through ecological agriculture has brought both ecological and economic benefits. To sum up, it can be seen that these ecological industrial models in karst areas are mainly based on agricultural development, and most of them are primary agricultural products, with a single industrial structure.

\subsection{Industrial Demonstration}

\subsubsection{Eco-Industry Application Demonstration}

From 2004 to 2006, six standardized demonstration bases for grassland animal husbandry stony desertification prevention and control were established in southwestern Guizhou, southern Guizhou and Guiyang, Guizhou province, and $2000 \mathrm{hm}^{2}$ of high-quality artificial forage base was built. Involving 1800 specialized households in grass planting and breeding, the demonstration effect is significant [32]. With the development of the demonstration project, beef cattle breeding demonstration areas have been established in Zhanjie, Liuchang and Anliu Town and Qingzhen City, Guizhou Province, with 952 farm households, 12,000 acres of artificial grassland and 3237 hybrid beef cattle [33,34]. Seven breeding demonstration sites have been established in Qinglong County, Guizhou Province. Each demonstration site has established a sheep breeding base, a high-quality mutton sheep fattening base, Artificial Forage Planting and an improvement base to combine demonstration, production and promotion [35]. In Xin'an Town, Pingguo County, Guangxi, a standardized meat rabbit breeding demonstration farm covering an area of $3.6 \mathrm{hm}^{2}$ and supporting three meat rabbit deep processing production lines has been established. It is the only demonstration base of meat rabbit breeding and processing in Guangxi [36]. These demonstration bases have promoted the development of ecological aquaculture in the surrounding areas, but the market for these products basically depends on the government or management enterprises. Their retail market is limited, and some products are basically sold domestically.

\subsubsection{Eco-Industry Demonstration Benefits Are Remarkable}

The demonstration of the three-dimensional ecological agriculture model of forest, fruit, tea, medicine and vegetables promoted the recycling and reuse of materials in the agricultural ecosystem and achieved a unified effect of ecological development, ecological environmental protection and renewable utilization of energy and economic benefits [34]. For example, the Guizhou Taro Stem Horticulture New Technology Development Company grows Lycoris radiata on barren hills and wasteland rented by farmers in Maizhi Village and Baiyi Township, Dongfeng Town, Wudang District. Add in the annual net income of CNY 3000 per mu and the wages of reemployed farmers, and the average annual income of farmers will reach more than CNY 12,000. In 2007, the project realized an output value 
of CNY 500,000, increasing farmers' income by CNY 100,000. Under the leadership of the company, Lycoris cultivation is advancing on the road of green development of "chain development and recycling", helping farmers increase their income [37]. Lin demonstrated the application of the principle of three-dimensional agriculture and the Directional Cultivation Technology of corn nutrition group seedling and practiced the three-dimensional planting and breeding mode of "rice, corn, fish, mushroom and vegetable" in a low-yield paddy field in the rock hill area of Northwest Guangxi. Compared with the control (simply planting double cropping rice), the output value increased by $579.5 \%$, the net income increased by $759.2 \%$ and the reciprocating utilization of agricultural resources was realized [38]. The economic effect of the model demonstration is remarkable, but the ecological products of most three-dimensional ecological industries are relatively singular and lack industrial innovation according to local conditions.

\subsection{Monitoring and Evaluation}

\subsubsection{Comprehensive Monitoring and Evaluation System of the Rocky Desertification} Ecological Environment System

The evaluation of ecosystem stability and sustainability before and after the treatment of eco-environmental vulnerable areas is conducive to ecosystem health management, and points out the direction for the correction of treatment methods and follow-up treatment paths of eco-environmental vulnerable areas. The comprehensive benefit evaluation of rocky desertification includes ecological benefits, economic benefits, and social benefits [39]. The evaluation of ecosystem stability after karst rocky desertification control mainly focuses on the evaluation of cultivated land fertility [40], water quality monitoring [41], soil and water conservation benefits [42], grassland animal husbandry benefits [43], characteristic forest industry benefit monitoring, shrub and grass restoration benefits [44], rocky desertification sensitivity, ecological restoration [45] and carbon sequestration benefits [46] and the comprehensive monitoring and evaluation of ecological benefits [47]. Sustainable benefits focus on the benefits obtained by ecological and social development in stability and protection in development [48]. The construction of various ecological models, research and development technology and application demonstrations have brought huge ecological benefits to karst areas, but the main socio-economic benefits depend on the ecological industrial cycle and sustainable development. Obviously, paying attention to its ecological benefits is often not enough. The socio-economic benefits before and after rocky desertification control are also one of the indicators for the evaluation of rocky desertification control. The ecological environment is the advantage of ecological resources, and high-quality ecological products are the transformation of ecological resources into economic resources, and their good quality corresponds to a wider market [48]. Therefore, the quality evaluation of ecological products is also very important for the evaluation of the benefits of rocky desertification control.

\subsubsection{The Quality Evaluation of Ecological Products Has Limitations}

Different growing environments have a great impact on the quality of ecological products. As one of the achievements in the governance of ecologically fragile areas, the quality of ecological products directly affects the economic benefits of ecological industries, and indirectly affects the demonstration and promotion of ecological industries. Generally, the quality of ecological agricultural products mainly includes the sensory quality, nutritional quality and flavor quality. Temperature, light, moisture, altitude and environmental pollution are the main factors affecting the quality of ecological products. The soil and water of the fragile karst ecological area have high contents of mineral nutrients such as calcium and magnesium, and the ecological environment pollution after rocky desertification treatment is small. Its good ecological environment is of great significance for improving product quality. Li Baojiang analyzed the content of mineral elements in the fruit of 22 apple varieties. The results showed that the varieties with high calcium and potassium content and low manganese and copper content had good fruit flesh, good storage resistance and 
good flavor quality. However, zinc content had little effect on fruit flavor, meat quality and storability, and the zinc content of high-quality varieties was relatively low [49]. Glenn used pear as the test material. Through calcium infiltration treatment, it was found that the pectin decomposition of the fruit after calcium treatment was slow during the storage period, which could maintain a high degree of fruit hardness and brittleness, showing strong storability [50]. Different crops have different adaptability to the environment [51], and the research on the change in fruit quality due to the influence of specific environments is not enough. The impact of ecological factors on fruit quality is difficult to quantify and has strong limitations, so it is difficult to establish a systematic ecological product quality evaluation system.

\subsection{Product Market}

\section{Ecological Product Information Does Not Match Market Information}

Under the influence of the Internet, the consumption habits and consumption patterns of the public are constantly changing, and ecological products have both advantages and disadvantages in market circulation. The advantage lies in its ecological value and in being green and organic, which conforms to the requirements of contemporary people for life. Its disadvantage also lies in its ecological value. Behind the ecological resources, there is higher technology, more labor and more precise strategies [52]. The products have higher prices than ordinary products. The scope of the market space for high-priced commodities depends on the purchasing power of consumers. For high-consumption groups, the market space is larger, while for low-consumption groups, the market space is small [53]. With the improvement in living standards, people pay more attention to the quality of products than before while paying attention to food and clothing. Moreover, chemical pesticides are widely used, resulting in the serious pollution of the soil and water in agricultural production. There are various heavy metal or harmful substances pollution problems in the products. Ecological products have gradually become a big trend and have become a necessity of life. Karst areas are mostly mountainous and impoverished areas with poor infrastructure and inconvenient transportation. In addition, most of the ecological products in karst areas are in the early stage of development, with no established brands and insufficient publicity. Therefore, most of the ecological product information does not match the market information, which leads to problems in production and operation in the later stage, and the ecological industry even faces the risk of bankruptcy.

\subsection{Value Realization and Promotion}

\subsubsection{Insufficient Supply Capacity of Ecological Products}

With the improvement in living standards and the popularization of the concept of ecological civilization, high-quality ecological products have increasingly become a concentrated reflection of the urgent needs of the people. When the pressure of economic growth on the ecology and the environment continues to increase, human beings use and transform the ecosystem on a large scale, and the over-exploitation, extensive utilization and extravagance and waste of resources that restrict sustainable development are common [54]. As the carrier of ecological products, the extensive exploitation and the inadequate protection of natural resources directly lead to the potential shortage of supply of ecological products and structural regional imbalance, resulting in the increasingly prominent contradiction between supply and demand, influencing people's pursuit of a better life. First, in the process of industrialization and urbanization, ecological land and the attached ecological resources are directly destroyed and eroded, and industrial emissions pollute the soil and atmosphere. In addition, the ever-increasing human demand for ecological products leads to the over-exploitation of resources, resulting in the degradation of ecological functions of resources, such as excessive deforestation and the mining of mineral products. A series of ecological problems have led to a serious decline in the supply capacity of ecological products. The ecological well-being of human beings has also been continuously reduced, and the supply of ecological products has been inefficient [18]. The fragile ecological 
environment of the karst area has high requirements for plants. Drought-tolerant and calcium-loving crops are the first choice for karst rocky desertification control. After rocky desertification control, the environmental carrying capacity of the ecosystem is limited, and the supply of ecological products is also limited.

\subsubsection{Various Modes of Realizing the Value of Ecological Products}

The spatial realization path of the value of ecological products is to take the value of ecological products as the guide; find the location, value and circulation elements in the space [55]; carry out reasonable planning, design, development and utilization of ecological space by scientific means; and improve the production efficiency and supply efficiency of ecological products. The trading of ecological products should follow the market rules and form a reasonable trading mechanism. Ecological products have the characteristics of dispersion, liquidity and regionality. Most of them cannot be directly incorporated into the specific tangible market for exchange, but they must still abide by the principles of openness, fairness and impartiality for trading or compensation. In essence, the market is to regulate the production, distribution, exchange and consumption of ecological products and solve the contradiction between economic development and ecological protection [56,57]. The value realization modes of ecological products include the following [30,58]:

(1) Industrial ecotype: Taking the ecological economic system as the main line, within the carrying capacity of the ecosystem, fully coupling and optimizing the industrial system, natural system and social system in a specific geographical space. Establish a circular economy ecological chain between different industries and enterprises, reduce waste discharge, reduce pollution and damage to the ecological environment and reduce the impact on the ecological environment during the entire life cycle from raw material extraction to product manufacturing, transportation, use and disposal.

(2) Ecological industry type: Promote ecological construction according to the law of industrialization, operate the ecosystem as a special capital-ecological capital, promote the transformation of ecological factors to production factors and ecological wealth to material wealth, establish a virtuous cycle mechanism between ecological construction and economic development and maintain and increase the value of ecological resources.

(3) Property right transaction type: Build a market-oriented operation mechanism, promote the formation of endogenous incentive power for ecological enterprises, and realize the commercialization and marketization of ecological resource asset products.

(4) Ecological compensation type: Ecological compensation is an institutional arrangement aimed at the protection and sustainable use of ecosystem services, focusing on economic means, regulating the interests of stakeholders and making conditional payments for compensated ecosystem services based on bilateral agreements.

\subsubsection{The Development and Improvement of Ecological Product Preservation Technology}

Product preservation has become an important link in the process of agricultural production. The losses caused by decay make producers and operators bear huge economic risks. Therefore, storage and transportation preservation has become a hot issue in agricultural technology research today. The ripening effect of ethylene, the respiration of fruit tissues and the growth of bacteria are the main factors affecting fruit quality and causing postharvest rot [59]. At present, the research on fruit preservation technology is mainly carried out for the above reasons. The proven technologies include chemical reagent preservation technology, natural plant extract preservation technology, physical preservation technology and genetic engineering technology. Based on the principles of strong operability, low cost, naturalness and being pollution-free [60], according to the actual conditions of the varieties in the demonstration area, finding suitable fresh-keeping and processing technologies to extend the shelf life of products will help farmers obtain higher economic benefits. In the actual preservation of fruits and vegetables, simply relying on one method to preserve freshness often cannot achieve good results, and a variety of methods are required to ensure the freshness of fruit and vegetable products. Vigorously 
strengthening the research of physical preservation technology, natural chemical substances, biological preservation technology and comprehensive preservation technology will provide new ways or means to preserve fresh fruits and vegetables. At the same time, it will also reduce the loss and waste of fruits and vegetables and other crops. With the continuous development of science and technology, more and more new materials and technologies have been gradually integrated into the preservation methods. For example, radiation preservation has achieved better results in the preservation of fruits and vegetables.

\subsubsection{The Promotion of Ecological Product Deep Processing Technology Is Limited}

One of the important ways to enhance the value of fresh fruits is to deep-process ecological products, retain nutritional value and eliminate the limitations of distance, transportation and time. With economic development and people's pursuit of high-quality food, fruit and vegetable processing, like other foods, is moving towards nutrition, highgrade, convenience, leisure, health and being green. High and new food processing technologies such as membrane separation, microencapsulation, supercritical extraction, ultra-high-pressure sterilization, freeze-drying, extrusion and biotechnology are more and more widely used in fruit and vegetable processing, which makes the processed products develop to high quality, high level, high grade and diversification [61]. The products of canned storage technology for the deep processing of fruits that we often see in our life, that is, canned fruits, fruit juice beverage processing technology, fruit sugar technology, dried fruit dehydration technology, vacuum freeze-drying technology, etc., have a good market prospect $[62,63]$, but the process is complex. However, to ensure economic benefits, its market price must be higher.

\section{Key Scientific and Technological Issues to Be Solved and Prospects}

\subsection{Basic Theory}

4.1.1. In View of the Low Added Value of Ecological Products, We Should Increase Human and Material Resource Investment and Improve the Added Value of Products

The added value of the product is low, and its profit margin is also very small. Agricultural products have low profits in the form of primary products, and high value-added products can not only meet the higher-level needs of consumers but can also bring higher economic value. It is one of the important ways to realize the value of ecological products. First, we can start with the production process of agricultural products and increase the added value of products by adding scientific and technological ingredients. Second, we can explore the characteristics of products, starting with their own natural environment and cultural background, find what other enterprises do not have and seek more attractive product characteristics than other enterprises. Third, cultural appeal can also become the added value of agricultural products. China is a country with strong regional color. Each region has its own local cultural characteristics. Fourth, we can diversify production and focus on individual demands. With the improvement in people's living standards, people's living needs are increasing. We are no longer satisfied with simple food and clothing but pay more and more attention to the quality of life. Fifth, we can improve the service concept and enhance the competitiveness of products. Traditional agricultural products enterprises have been mainly selling primary agricultural products. In today's increasingly fierce market competition, simply selling has become a little outdated. By strengthening the connection with product sources and consumer terminals, companies can actively tap customer needs, strive to provide smoother and more complete production and sales services, switch on the chain between the terminal market and product sources and satisfy product supply. Sixth, product packaging can enhance the added value of products. Many enterprises do not regard the packaging of agricultural products as an essential or worthy link. However, like other products, agricultural products need better packaging to reflect their individuality and differences for attracting a wide range of consumer groups. 
4.1.2. In View of the Characteristics of Supply and Demand of Ecological Products and High Market Prices, Strengthen Cooperation among Various Entities to Find the Most Suitable Production and Marketing Model

Ecological products can be divided into market ecological products and public ecological products. Market ecological products are products or services produced by human development and the utilization of natural elements [64]. It includes ecological food, harvested forest wood, fish caught in the ocean, clean water extracted from rivers, minerals and ecotourism. For market ecological products, their value can be measured by currency, which is reflected in the price formed in the open and competitive trading market. The price of a product is not determined by the owner, but by market supply and demand. The current high price of some ecological products in the market is caused by scarcity. The supply subjects of ecological products include the government, enterprises, public organizations and individuals, and each supply and demand subject finds the most suitable production and sales model according to local conditions. According to the supply and demand characteristics of ecological products, the ecological market is classified to better strengthen the industrialization and commercialization of ecological products. They have formed a variety of production and sales models according to different market needs. The main models currently existing in the research area are the joint development models such as "leadership by party branch + enterprise driven + cooperative promotion + farmer participation" and "substitute planting instead of raising". The main body of the realization of the value of public ecological products is the ecological compensation policy under the leadership of the government, which is supplied by the natural ecosystem, and ecological resource products without the participation of human activities, such as clear air, clean water, pleasant climate, green space and pollution-free soil. It cannot be quantified through the market and mainly depends on government supply, but there are obvious inefficiencies in a single government supply. Therefore, a better supply mode of public ecological products still needs to be further explored based on giving full play to the role of the market mechanism.

\subsection{Pattern Construction}

4.2.1. In View of the Application Effects of Different Ecological Models, It Is Necessary to Optimize the Combination According to Each Model

In the special karst environment, the selection of organisms is strict. Only those crops with biological characteristics such as drought tolerance and calcium preference can grow healthily. In order to achieve a better application effect, we should summarize and vigorously develop rocky desertification control technologies; optimize, assemble and support these technical measures in karst areas and build an integrated system of comprehensive rocky desertification control technologies; form a rocky desertification control technology model with significant ecological benefits, industrial benefits and benefits to people's livelihood; and integrate with the technology of ecologically derived industries $[11,65]$. Karst rocky desertification is the result of the interaction between the karst process and the social and economic process. To completely curb the rocky desertification process and rebuild the beautiful mountains and rivers in the rocky desertification area, we must innovate the traditional ecological governance model of the past and establish a "people-oriented" concept that pays close attention to people's livelihood in rocky desertification areas. The comprehensive control of rocky desertification is carried out from the four levels of production (technology), life, ecology and development, so as to obtain the best effect of rocky desertification control and make it lasting and consolidated [7].

4.2.2. In Response to the Single Problem of the Karst Ecological Industry Structure, Adjust the Industrial Structure and Optimize the Allocation of Resources

Since the reform and opening, China's three industrial structures have become more and more reasonable, which generally conforms to the general law of industrial development, but the level of industrial structure is low. Ecological industry is the inheritance of "traditional industry" and "modern industry" and the product of social and economic 
development. In the industrial structure, agricultural products, animal husbandry products and other low value-added industrial products still account for a large proportion, while the proportion of high value-added industries is low. Therefore, at a certain stage of agricultural development, it is necessary to adjust the industrial structure and expand the proportion of high value-added products; at the same time, efforts should be made to increase the number of dominant comparative advantage products in the product space and strengthen the development of service industry in addition to high value-added products. Different development stages of product space have differentiated advantageous industrial structure. For promoting the development of emerging industries, it is necessary to prevent limited resource element endowments from being invaded by "zombie industries", establish a healthy exit mechanism, guide the exit of backward industry markets and achieve optimal allocation of resources.

\subsection{Industrial Demonstration}

4.3.1. Aiming at the Problem of Insufficient Circulation of Ecological Products, Strengthen the Industrialization and Commercialization of Ecological Products

The industrialized management of ecological capital is a practical means to realize the value of ecological products. The 18th CPC National Congress proposed that to improve the supply and demand capacity of production products, we should use various publicity means such as network media, television, and newspapers to strengthen publicity, guidance, and education for people, and constantly improve the farmers' awareness of developing and protecting ecological products. A brand should be established, and we should change from "product manufacturing" to "brand management". A brand is a sign of commodity quality, and more and more people believe in the power of brands. We should make full use of agricultural science and technology, focus on product quality and safety and strengthen research. We should break the existing sales model and establish a new diversified sales model, such as accelerating the entry of original ecological agricultural products into supermarkets, promoting online marketing, further improve the ability of farmers to open online stores and develop cooperative sales [66].

4.3.2. In View of the Single Type of Economic Fruit Forests in Karst Areas, Strengthen Standardized Planting of Economic Fruit Forests in Karst Areas to Promote Industrial Development

At present, there are too few demonstration areas for the development of ecological industries derived from fruit forests in karst areas. We should increase demonstration sites, strengthen demonstration efforts and strengthen influence. First, studies on the coupling mechanism between the fruit forest cultivation base and the tourism landscape in rocky desertification area are needed. The fruit forest cultivation base can be coupled with the tourism landscape to form a fruit forest tourism base. Second, deep processing by fruit forest. The processed fruit forest is now mostly processed into daily food, and its deep processing can also be expanded to other aspects. It can be processed into health products and daily necessities, promote the model of "farmers + companies + scientific" research institutions, encourage farmers to try out simple processing independently and encourage farmers to cooperate with companies, scientific research institutions and the government to develop the deep processing of fruit forest. Third, strengthen the market promotion of economic fruit forest, with domestic and foreign markets as the main body and foreign markets as the next promotion goal.

\subsection{Monitoring and Evaluation}

For Product Quality Testing and Evaluation Issues, a Systematic Quality Evaluation Index System Should Be Established to Provide Theoretical Basis and Technical Guidance for the Development of Karst Ecological Industrial Products

For the evaluation of ecological benefits, the evaluation indicators in the rocky desertification control model have gradually become more perfect, but the quality of the ecological products itself has not been paid enough attention. Product quality is the most 
fundamental value standard for production and sales, and an important factor affecting the development of industrialization. According to the development status of derivative products in rocky desertification areas, it is an urgent problem to evaluate the quality of crops scientifically and accurately in karst rocky desertification areas, and to establish a quality evaluation index system. Consumers are the ultimate users of products and have a direct say in product quality. According to consumers' cognitive level and willingness of product quality indicators, to study the cognition of product quality in the market, it is necessary to establish an evaluation index system suitable for the market and develop better quality evaluation technologies. For example, nondestructive testing technology has the advantages of fast and nondestructive testing. Rational use of this technology is an important means to study fruit quality. Nondestructive testing technology overcomes the shortcomings of traditional physical and chemical testing methods, such as destroying samples, being time-consuming and laborious, cumbersome operation and so on [67]. It has been successfully applied to the quality inspection of fruits and vegetables. At present, most research focuses on a single quality, while there are relatively few studies on the simultaneous detection of multiple indicators and comprehensive quality classification, and there is a lack of research on comprehensive quantitative evaluation standards for nutrients such as taste and texture. A development trend of nondestructive testing is to analyze the correlation between appearance quality parameters and pulp quality, visually analyze the spatial distribution of each component, analyze the action mechanism between each component, build a more comprehensive and effective evaluation index and scientific and reasonable comprehensive evaluation system, establish a stable and reliable testing model and realize grading.

\subsection{Product Market}

In View of the "Difficult to Buy" and "Difficult to Sell" Problems of Ecological Products, It Is Necessary to Master the Market Supply and Demand Information, Establish Brands, Design Packaging, Expand the Influence of Ecological Products in the Demonstration Area and Expand the Market

Most of the ecological products produced in karst areas do not have their own brands, and it is difficult to make profits even if the quality is high. The products are purchased by foreign merchants at low prices and sold at high prices. If the same product is labeled with different brand logos, it may produce wide price differences [68]. The influence of the brand is not limited by geographical conditions, and the publicity direction is wider. Therefore, by excavating, cultivating and developing traditional advantageous eco-industrial product brands with unique regional characteristics and focusing on product quality, we will create high-quality products such as pollution-free agricultural products, green food, organic agricultural products and geographical indications of agricultural products ("three products and one standard"). The brand of eco-industrial products improves the premium ability [69] through the establishment of brand image of agricultural products, solidifies the public's positioning of product value, realizes the value-added of ecological products, enhances the market competitiveness of characteristic ecological products, steadily improves farmers' income and promotes the development of the regional agricultural economy.

\subsection{Value Realization and Promotion}

4.6.1. In View of the Imbalance between the Supply and Demand of Ecological Products, It Is Necessary to Propose Technologies to Enhance the Value of Ecological Products and Enhance the Supply Capacity of Ecological Products

Ecological products can maintain ecological security, ensure ecological adjustment functions, build a good living environment and maintain people's lives and health. It also has its particularity, such as fragility characteristics: Although it can be regenerated, it will be exhausted if overused; regional characteristics play a role in a certain spatial range. So, it has ecological properties. An ecological product is an ecological resource that can bring economic and social benefits, that is, a kind of ecological capital, especially a natural ecosystem that can provide environmental comfort [70]. The harm of shortages of 
ecological products is very serious, which not only directly affects the carrying capacity of the population and economy in ecological time but also directly affects the survival of human beings. The current problems in our country are that there is insufficient awareness of the seriousness of ecological security problems, weak institutions and scientific and technological capabilities to manage ecological security and we are unable to take effective measures to continuously prevent ecological disasters and facing enormous pressure to maintain national ecological security. In view of this, it is recommended to take improving the supply capacity of ecological products as a basic national policy [14,71]. First, it is necessary to continue to increase the national investment in afforestation, forest vegetation and wetland protection; expand the area of ecological product production bases; and take strict measures to protect existing forest land and wetlands like the protection of cultivated land [72]. Second, it is necessary to strengthen the management of existing forests and wetlands, increase forest management investment, strengthen scientific forest management measures and improve forest quality and productivity of forest land ecological products [73]. Third, it is necessary to strengthen the functions of the national forestry administrative department, establish its role in ensuring national ecological security, strengthen its function as the national ecological product production and supervision department and strengthen coordination capabilities [74].

4.6.2. For Some Ecological Products That Cannot Directly Enter the Market, We Should Build the Value of Ecological Products and Realize the Value

The key to promoting the realization of the value of ecological products lies in balancing the interest development demands of the ecological environment and economic growth. Local governments and residents are the interest subjects of the realization of the value of ecological products. To improve the enthusiasm of ecological environment protection and internalize the opportunity cost of protection and development, it is necessary to build the value of ecological products to realize the value, which is important for maintaining ecological security. It is of great practical significance to promote the balanced development of economic, social and ecological protection and the harmonious coexistence between man and nature [31]. Gross ecosystem product (GEP) refers to the sum of the value of final products and services provided by a certain regional ecosystem for human well-being and sustainable economic and social development, including regulating the value of service products, cultural service products and material products. GEP, as a value indicator of ecosystem services to human society, can uniformly characterize the functions of different types of natural capital. Therefore, Shi Minjun believes that GEP represents potential value, and the starting point of GEP accounting is to maintain the stock and function of key natural capital, to protect green water and green mountains and maintain the potential value [70]. In terms of ecological value accounting, the commonly used theoretical methods are mainly divided into three categories: actual market method, alternative market method and virtual market method and related extension methods, which have been applied in practice, mainly through the equivalent factor method (EFM) and the functional price method (FPM) [56].

4.6.3. In View of the Promotion of Ecological Agricultural Products Preservation and Deep Processing Technology, It Is Necessary to Propose New Technologies That Are More Suitable for the Value Enhancement of Demonstration Areas to Provide Technical Support for Product Marketization

With the improvement in living standards, people pay more and more attention to the intake of nutrients in products, and its storage and preservation market has a bright future. A large quantity of studies shown that there are many factors that affect the quality of product storage. Two aspects are the most important. On the one hand, the role of various growth regulators before harvesting and the use of different types of fertilizers during the growth process and the harvesting period is different, and the fruit maturity is different. Different maturities have different respiration rates after harvest, and the preservation time is also different. On the other hand, there are various post-harvest storage methods. 
Today, the most common storage methods are mainly divided into physical methods, such as low-temperature storage. Each fruit has its own freezing point. During the storage process, if the temperature is too low, it will cause low temperature damage to the fresh fruit. Therefore, the temperature control of low temperature preservation is the key [75]. The principle of controlled atmosphere storage is to keep the fruit in artificially controlled air for airtight storage, reduce the respiration intensity of the fruit, inhibit other metabolic processes of the fruit, delay the ripening of the fruit and extend its storage period. Modified atmosphere storage is divided into two categories, one is CA (Controlled Atmosphere) storage and the other is MA (Modified Atmosphere) storage. The physical method is the most used method, which is simple to operate and easy to promote [76]. Chemical methods, such as 1-methylcyclopropene (1-MCP) treatment, chlorine dioxide treatment, coating treatment, ozone treatment, etc., use some chemical reagents, which are difficult to control. In addition to the most common storage and preservation methods, there are methods such as ultra-low oxygen treatment, heat treatment, irradiation treatment and biological preservation technology [77]. More and more fresh-keeping technologies have appeared one after another, but due to various factors such as economic and technical conditions, some methods have not been widely promoted, but the increasing maturity of fresh-keeping technologies will also bring economic benefits to the fruit market. In the future research work, people will pay more attention to the quality parameters of fruit and vegetable flavor, quality and nutrition beyond freshness and establish a comprehensive freshness system to evaluate the freshness, maturity, damage, flavor, taste, color and safety of fruits and vegetables.

\section{Conclusions}

In conclusion, the research on the industrial chain of ecological products in karst ecologically fragile areas focuses on the links of planting and production, and the research on the sales environment connected with the consumer market is relatively weak. Due to the particularity of China's karst areas, their economic benefits have become an important indicator of ecological benefit evaluation and one of the important indicators to measure the effectiveness of rocky desertification control. Therefore, we should pay attention to the monitoring and evaluation of comprehensive management of rocky desertification but also pay attention to the development of local economic construction to promote the development of industries in the wider rocky desertification areas. Through the virtuous circle of "industry improves ecology, ecology gives back to industry", the sustainable development of economy, ecology and society is realized. Specifically, there are the following aspects:

(1) Increase capital investment and policy preference, improve infrastructure conditions and protect fragile ecological environments. Use the effective integration of agriculture-related funds, poverty alleviation funds and other project funds to comprehensively control mountains, water, forests, fields and roads in rocky desertification areas. Improve the ecological environment and infrastructure conditions in rocky desertification areas and lay the foundation for the development of ecological product logistics.

(2) Continuously monitor the basic indicators of the ecological industry in the rocky desertification area, establish an ecological product quality evaluation system and promote the sustainable development of the industry. The continuous expansion of ecological benefits and the increasing vegetation coverage are the ultimate results of rocky desertification control. Increasing the monitoring of ecological sustainability after rocky desertification control is conducive to the higher and faster development of the ecological industry. Product quality is the foundation of product production in market competition. Establishing an ecological product quality evaluation system and continuously improving the quality of ecological products is an important foundation for the sustainable development of the ecological industry.

(3) Accelerate the adjustment of agricultural industrial structure and develop ecological animal husbandry and characteristic forest and fruit industry. Fully absorb the successful model of rocky desertification control derivative industries; develop ecological 
agriculture, forestry and animal husbandry that are in line with the karst fragile ecological environment protection; form a rational use of resources and a diversified development pattern of industrial projects; and enhance the supply capacity of ecological products.

(4) Build a comprehensive and objective way of realizing the value of ecological products. Karst areas take the road of diversified industrial development and relying on a single government investment is not enough. How to break through the dilemma of local economic development and ecological protection after ecological restoration is a difficult problem after rocky desertification control. Cultivate leading enterprises, produce and process agricultural and sideline products, create high-efficiency demonstration parks, develop agricultural tourism, and promote the high integration of secondary and tertiary industries, and give full play to the superior ecological resources of the karst area.

(5) Build a sales platform, expand sales channels, and realize integrated services of production, supply, and sales. The development of the ecological industry for rocky desertification control has brought ecological products to the local area. One of the important paths to realize the value of ecological products is to enter the market and participate in market competition. The competitive advantage of ecological products lies in their high quality. Make full use of the "Internet + " method to develop product brands, and use brand benefits to expand product awareness. Understand the supply and demand of agricultural special products nationwide and around the world, balance the supply and demand of ecological products and form a standardized, perfect and wide-ranging sales and service system.

Author Contributions: Conceptualization, K.X., Z.L. and H.S.; methodology, K.X. and Z.L.; software, H.S.; data curation, H.S. and. L.L.; writing-original draft preparation, H.S.; writing-review and editing, K.X. and L.L.; project administration, K.X.; funding acquisition, K.X. All authors have read and agreed to the published version of the manuscript.

Funding: This research was supported by the China Overseas Expertise Introduction Program for Discipline Innovation: Overseas Expertise Introduction Center for South China Karst Eco-environment Discipline Innovation (D17016); the Key Science and Technology Program of Guizhou Provence: Poverty Alleviation Model and Technology demonstration for Ecoindustries Derivated from the karst desertification control (No. 54112017 Qiankehe Pingtai Rencai) and the World Top Discipline Program of Guizhou Provence: Karst Eco-environment Science (No. 1252019 Qianjiao Keyan Fa).

Institutional Review Board Statement: Not applicable.

Informed Consent Statement: Not applicable.

Data Availability Statement: Data are contained within the article.

Acknowledgments: For the smooth completion of this article, I would like to thank my advisors Z.L. and K.X. for their support and guidance throughout the process, who provided me with a learning platform, learning methods, technology, financial support and modification comments. Thank you brother L.L. for the modification comments and the methods I brought with me in my study and also thanks the same group of students for their encouragement and help.

Conflicts of Interest: The authors declare no conflict of interest.

\section{References}

1. Yang, M.D. On the Fragility of Karst Environment. Yunnan Geogr. Environ. Res. 1990, 2, 21-29.

2. Ford, D.; Williams, P. Karst Hydrogeology and Geomorphology, 3rd ed.; Wiley: Chichester, UK, 2007; pp. $20-436$.

3. Jiang, Z.C.; Lian, Y.Q.; Qin, X.Q. Rocky desertification in Southwest China: Impacts, causes, and restoration. Earth-Sci. Rev. 2014, 132, 1-12. [CrossRef]

4. Chen, Y.B.; Xiong, K.N.; Chi, Y.K. Problems and countermeasures of agricultural development in the karst area of southwest China. Jiangsu Agric. Sci. 2019, 47, 17-21.

5. Wang, K.L.; Zhang, C.H.; Chen, H.S.; Yue, Y.M.; Zhang, W.; Zhang, M.Y.; Qi, X.K.; Fu, Z.Y. Karst landscapes of China: Patterns, ecosystem processes and services. Landsc. Ecol. 2019, 34, 2743-2763. [CrossRef]

6. Wang, K.L.; Su, Y.R.; Zeng, F.P.; Chen, H.S.; Xiao, R.L. Ecological Process and Vegetation Restoration in Karst Region of southwest China. Res. Agric. Mod. 2008, 29, 641-645. 
7. Jiang, Z.C.; Li, X.K.; Zeng, F.P.; Qiu, S.J.; Yan, D.; Luo, W.Q.; Qin, X.Q.; Xie, Y.Q.; Funing, L. Study of Fragile Ecosystem Reconstruction Technology in the Karst Peak-cluster Mountain. Acta Geosci. Sin. 2009, 30, 155-166.

8. Yuan, D.X. Challenges and opportunities for karst research of our country under the new situation. Carsologica Sin. 2009, 28, 329-331.

9. Su, W.C. Eco-environmental fragility in Guizhou Karst Mountain and its ecological rehabilitation. China Environ. Sci. 2000, 20, 547-551.

10. Xiong, K.N.; Li, J.; Long, M.Z. Features of Soil and Water Loss and Key Issues in Demonstration Areas for Combating Karst Rocky Desertification. Acta Geogr. Sin. 2012, 67, 878-888.

11. Xiong, K.N.; Zhu, D.Y.; Peng, T.; Yu, L.F.; Xue, J.H.; Li, P. Study on Ecological industry technology and demonstration for Karst rocky desertification control of the Karst Plateau-Gorge. Acta Ecol. Sin. 2016, 36, 7109-7113.

12. Herman, E.K.; William, E.C.; James, M.F. Engineering for Ecological, Sociological, and Economic Compatibility. IEEE Trans. Syst. Man Cybern. 1972, SMC-2, 319-331.

13. Arthur, P.J.M. The Refinement of Production. In Ecological Modernization Theory and The Chemical Industry; Wageningen University and Researchcenter Publications: Wageningen, The Netherlands, 1995; pp. 283-389.

14. Zeng, X.G.; Yu, H.Y.; Xie, F. Concept, Classification and Market Supply Mechanism of Ecological Products. China Popul. Resour. Environ. 2014, 24, 12-17.

15. Yu, M.; Li, W.M.; Gao, S.J.; Gu, S.Z. A Theoretical Analysis of Ecological Products and Their Value Realization. Dev. Stud. 2020, 2, 47-56. Available online: https:// kns.cnki.net/kcms/detail/detail.aspx?FileName=FZYJ202002006\&DbName=CJFQ2020 (accessed on 8 February 2022). (In Chinese)

16. Li, L.; Fan, Z.H.; Xiong, K.N.; Shen, H.T.; Guo, Q.Q.; Dan, W.H.; Li, R. Current situation and prospects of the studies of ecological industries and ecological. Environ. Res. 2021, 201, 111613-111640. [CrossRef] [PubMed]

17. Wang, L.Q.; Xu, H. Study on the theoretical of the added value of agricultural products. Econ. Trade Pract. 2018, 22, 147-148 Available online: https:/ / kns.cnki.net/kcms / detail/detail.aspx?FileName=JMSA201822114\&DbName=CJFQ2018 (accessed on 8 February 2022). (In Chinese)

18. Tang, Q.N. Resrarch on Supply System of Ecological Products; Southwest University of Political Science and Law: Chongqing, China, 2017.

19. Tang, Q.N. Study on the Market Supply System of Eco-products. Frontiers 2019, 19, 112-115. (In Chinese) [CrossRef]

20. Zheng, Q.W. Key Issues in Realizing the Value of Ecological Products. Zhejiang Econ. 2019, 21, 25. Available online: https://kns. cnki.net/kcms/detail/detail.aspx?FileName=ZHEJ201921021\&DbName=CJFQ2019 (accessed on 8 February 2022). (In Chinese)

21. Luo, Y.; Xiong, K.N.; Long, C.C.; Zhu, J. Interaction between Environment Degradation and Rural Poverty of Karst Regions in Guizhou. Guizhou Agric. Sci. 2009, 37, 207-211.

22. Xiong, K.N.; Xiao, J.; Zhu, D.Y. Research progress of agroforestry ecosystem services and its implications forindustrial revitalization in karst regions. Acta Ecol. Sin. 2022, 3, 851-861. (In Chinese)

23. Chen, Y.B. Researches on the Integration of Techniques and Models for Karst Rock Desertification Comprehensive Treatment in Guizhou Province; Guizhou Normal University: Guiyang, China, 2008.

24. Wang, K.L.; Yue, Y.M.; Chen, H.S.; Wu, X.B.; Xiao, J.; Kun, Q.X.; Wei, Z.; Du, H. The comprehensive treatment of karst rocky desertification and its regional restoration effects. Acta Ecol. Sin. 2019, 39, 7432-7440.

25. Xiong, K.N.; Chen, Q.W. Discussion on karst rocky desert evolution trend based on ecologically comprehensive treatment. Carsologica Sin. 2010, 29, 267-273.

26. Xiong, K.N.; Cheng, Y.B.; Chen, H.; Lan, A.J.; Sui, Z. Midas Touch of Karst: The Technology and Model of Rocky Desertification Rehabilitation in Guizhou; Guizhou Science and Technology Press: Guiyang, China, 2011.

27. Wang, K.L.; Chen, H.S.; Zeng, F.P.; Yue, Y.M.; Zhang, W.; Fu, Z.Y. Ecological Research Supports Eco-environmental Management and Poverty Alleviation in Karst Region of Southwest China. Bull. Chin. Acad. Sci. 2018, 33, 213-222.

28. You, X. Development model of ecological economy governance based on the typical karst landform of three autonomous prefectures in south of Guizhou. Guizhou Sci. 2016, 34, 46-51.

29. Sun, J.; Liu, Z.Q.; Zhu, D.Y.; Li, Y.; Li, K.P.; Wang, J. Evaluation on Soil Qualities of Different Ecological Restoration Models in Rocky Desertification Control Area. Res. Soil Water Conserv. 2019, 26, 222-228.

30. Cui, H.Y. The Method of Promoting Farmers Employment Analysis in the Ecologically vulnerable areas-A Case Study in Western Jilin. Adv. Mater. Res. 2012, 524, 3509-3513. [CrossRef]

31. Wan, J.; Cai, Y.L. Land degradation and eco-reconstruction in fragile karst ecosystem: The case of guanling county, Guizhou province. China Popul. Resour. Environ. 2003, 13, 52-56.

32. Fan, Z.L. The mechanism and mode of ecological product value realization. China Land. 2020, 35-38. [CrossRef]

33. He, X.J.; Wang, L.; Ke, B.; Yue, Y.M.; Wang, K.L.; Cao, J.H.; Xiong, K.N. Progress on ecological conservation and restoration for China Kant. Acta Ecol. Sin. 2019, 39, 6577-6585.

34. Hu, Z.W. The Economical Benefit and Developing Model of Ecological Industry of Rocky Desertification Control in Karst Area; Guizhou Normal University: Guiyang, China, 2014.

35. Chen, H.S.; Yue, Y.M.; Wang, K.L. Comprehensive control on rocky desertification in karst regions of southwestern China: Achievements. problems, and countermeasures. Carsologica Sin. 2018, 37, 37-42. 
36. Wu, K.Y.; Jiang, Z.C.; Luo, W.Q.; Tan, X.Q. Effect of tri-dimensional eco-agriculture pattern in Karst peak-cluster zones-A case study of Guohua Demonstration Area in Pingguo County, Guangxi Zhuang Autonomous Region. Chin. J. Eco-Agric. 2008, 16, 1197-1200. [CrossRef]

37. Li, Y.X. Model, and characteristics of development of ecological agriculture in Guiyang. In Proceedings of the Symposium on Efficient Ecological (Organic) Characteristic Agriculture in Guizhou Province, Guiyang, China, 1 December 2011; pp. $269-274$.

38. Lin, D.J.; Liang, Q.B.; Luo, H.F. A Preliminary Report to the Test of the Effect of High output and High Effect Spacial Planting and Breecding in Low Output Peddy Fields in Rocky Region. J. Guangxi Agric. 1994, 2, 21-26. (In Chinese)

39. Dong, X.C.; Ning, X.K.; Yun, Z.D.; Lan, J.C.; Liao, J.J.; Cao, Y.; Yi, L.X. Risk assessment of karst ecological environments: A case study of Guizhou Province. Carsologica Sin. 2019, 38, 713-721.

40. Xiao, J.; Liu, Z.Q.; Li, K.P.; Wen, Y.Q.; Chen, H. Diagnosis and Evaluation of Soil Fertility in Economic Fruit Forests of Rocky Desertification Control Area. J. Sichuan Agric. Univ. 2018, 36, 659-664.

41. Zhang, C.Y.; Liu, Z.Q.; Liu, Z.J.; Li, Y.; Xing, K. Comprehensive Analysis of Water Pollution in Karst Areas During Nomal Water Season-Taking Dolomite Karst World Natural Heritage Site in Guizhou Province as an Example. Bull. Soil Water Conserv. 2019, 39, 253-259.

42. Yan, P. Soil and Water Conservation Model and Benefit Monitoring and Assessment of Karst Rocky Desertification on Control; Guizhou Normal University: Guiyang, China, 2016.

43. Liu, K.X.; Xiong, K.N.; Guo, W.; Yang, S.M.; Zhang, J.H. Grassland Efficient Production and Potential Evaluation of Grassland Animal Husbandry in Karst Desertification Area Acta Ecologiae Animalis Domalis Domastici. J. Domest. Anim. Ecol. 2018, 10, 64-69.

44. Ji, C.Z. Monitoring and Evaluation of Eco-Benefits of Forest-Shrub-Grass Restoration and Superior Characteristic Forest Industry in the Karst Rocky Desertification Control; Guizhou Normal University: Guiyang, China, 2020.

45. Li, R.B.; Hong, H.L.; Qing, T.; Yang, G.B.; An, Y.L.; Li, Y. Grading method for the evaluation index on the karst eco environmental sensitivity-A case study under the land-use style in Duyun city. Carsologica Sin. 2009, 28, 87-93.

46. Yang, L. Evaluations of Carbon Sink Benefit under the Ecological Restoration Model of Karst Rocky Desertification on Control; Guizhou Normal University: Guiyang, China, 2016.

47. Chen, H.Y. Ecological Monitor and Benefit Evaluation of the Integrated Management in the Karst Rocky Desertification Regions; Guizhou Normal University: Guiyang, China, 2016.

48. Xiong, K.N.; Liu, L.C.; Luo, Y. The Evaluation Studies Progress and Prospects of Sustainable Development in Rocky Desertification Region. Ecol. Econ. 2012, 1, 44-49.

49. Li, B.J.; Lin, G.R.; Liu, F.J. Relationship Between Fruit Quality, Storability and Mineral Composition of Apples. J. Fruit Sci. 1995, 12, 141-145.

50. Glenn, M.G. Ecological Capital Effect of calium on cell wall structure, protein phosphorilation and protein profile in apples. Plant Cell Physiol. 1988, 29, 565-572.

51. Guo, K.; Liu, C.C.; Dong, M. Ecological adaptation of plants and control of rocky-desertification on karst region of South-west China. Chin. J. Plant Ecol. 2011, 35, 991-999. [CrossRef]

52. Jin, W.F.; Wang, S.J.; Deng, S.Z.; Liu, Y. Review on the impact of the internet on spatial organization of retail. Hum. Geogr. 2018, 33, $1-10$.

53. Song, N.; He, Y.L.; Mao, Y.Q. Research on Spatial Distribution and Influencing Factors of Tea Sales Market in China. J. Tea Commun. 2021, 48, 136-144.

54. Yao, Z.; Sun, Y.; Wang, W. Analysis of Economic Relations in Realizing the Value of Eco-products. J. Shijiazhuang Univ. Econ. 2019, 42, 53-62.

55. Cai, Z.C.; Hong, D.W. Economic Analysis on the Supply of Ecological Products. Econ. Res. Guide 2020, 18, 3-5.

56. Liu, J.Y.; Mou, D.G. Research Progress of Ecological Product Value and Its Realization Mechanism. Ecol. Econ. 2020, 36, $207-212$.

57. Jin, C.; Lu, Y.Q. Review and Prospect of Research on Value Realization of Ecological Products in China. Econ. Geogr. 2021, 41, 207-213. [CrossRef]

58. Liu, J.N. Research on the Strategies of Promoting the Market Value of Regiona Specialty Products; Jilin University: Jilin, China, 2016.

59. Cao, T.T.; Zeng, K.F.; Deng, L.L. Research progress on the application of light irradiation in postharvest storage and preservation of fruits and vegetables. Food Ferment. Ind. 2021, 11, 1-8.

60. Shen, F.J.; Yan, Z.L.; Zhong, L.E. Progress of Modern Preservation Technology and Botanical Preservatives for Fruits and Vegetables. J. Henan Agric. Sci. 2016, 45, 7-12.

61. Singh, N.P. Fruit and Vegetable Preservation; Rajdhani Printers: Dellii, India, 2007; pp. 10-357.

62. Daniel, V.; María, S. Postharvest Biology and Technology for Preserving Fruit Quality, Postharvest Biology and Technology for Preserving Fruit Quality; CRC Press: New York, NY, USA, 2010; pp. 58-192.

63. Golding, R.B.H.W. Advances in Postharvest Fruit and Vegetable Technology; Taylor \& Francis Group: New York, NY, USA, 2015; pp. 20-108.

64. Wang, F.Y. Construction of Quality Evaluation and Market Response Study for Derivatives of Rocky Desertification Control—A Case Study of Zanthoxylum and Hylocereus; Guizhou Normal University: Guiyang, China, 2019.

65. Cao, J.H. Research on Pricing the Value of Ecosystem Products and Services. Ecol. Econ. 2016, 32, $24-28$.

66. Gui, Q.H. Consumer Characteristics in Market Space and Its Marketing Enlightenment. Commer. Times 2011, 20, 29-30. 
67. Mo, Y.Y. Nondestructive quality testing of fruit. Physics 2004, 11, 848-851. Available online: https://kns.cnki.net/kcms/detail/ detail.aspx?FileName=WLZZ200411019\&DbName=CJFQ2004 (accessed on 8 February 2022). (In Chinese).

68. Song, M.J. Analysis of the Brand Value of Agricultural Products: Taking Guangfeng Majia Grapefruit as an Example; Jiangxi Normal University: Nancang, China, 2020.

69. Bu, C.L. Study on Spatial Distribution Characteristics and Certification Effect of Products of Chinese Agro-Product Geographical Indication; Chang'an University: Xi'an, China, 2020.

70. Liu, G.Y.; He, P.; Yang, W.Y. Agro-ecological product and its value realization pathway. Chin. J. Appl. Ecol. $2021,32,737-749$.

71. Yu, H.; Zheng, J. Research on the Ecological Products Optimal Supply under the Perspective of Microeconomics. Anhui Agri. Sci. Bull. 2017, 23, 3-7.

72. Zhang, X.X.; Dong, W.; Wei, Q.G. Morphological Transformation and Value Realization of Ecological Capital and Ecological Products: Expansion Analysis Based on Marxist Capital Cycle Theory. Ecol. Econ. 2020, 36, 213-218.

73. Liao, M.L.; Pan, J.H.; Sun, B.W. Analysis of the Connotation and Realization Path of Ecological Products. Econ. Reform 2021 1, 12-18. Available online: https://kns.cnki.net/kcms/detail/detail.aspx?FileName=JJTG202101003\&DbName=DKFX2021 (accessed on 8 February 2022).

74. Sun, B.W.; Peng, X.S. Realization Mode, Key Issues and Institutional Guarantee System of Ecological Product Value. Ecol. Econ. 2021, 37, 13-19.

75. Valero, D.; Díaz-Mula, H.M.; Zapata, P.J.; Guillén, F.; Martínez-Romero, D.; Castillo, S.; Serrano, M. Effects of alginate edible coating on preserving fruit quality in four plum cultivars during postharvest storage. Postharvest Biol. Technol. 2013, 77, 1-6. [CrossRef]

76. Shekarchi, M.; Naghshiband, H.R.; Mostoufi, Y.; Zamani, Z.; Pirali, H.M. The Effects of Fruit Maturity and 1-Methylcyclopropene (1-MCP) Treatment on $\alpha$-farnesene Metabolism in Scald Resistant and Susceptible Cultivars of Apple Fruit. J. Med. Plants 2009, 8, 99-109.

77. Barbosa-Cánovas GVRosenthal, A.; Deliza, R.; Welti-Chanes, J. Fruit Preservation Novel and Conventional Technologies, Fruit Preservation Novel and Conventional Technologies; Springer Science Business Media, LLC: New York, NY, USA, 2018. 